Li, Z., Lytvynenko, I.P., \& Philippoff, K.S. (2021). Reexamining the Economic Recovery Tax Act of 1981: Evidence from Innovative Efficiency. Copernican Journal of Finance \& Accounting, 10(2), 27-43. http://dx.doi.org/10.12775/CJFA.2021.006

\author{
ZHAOCHU LI* \\ UM-Flint School of Management
}

Iryna P. LytVynenKo**

KARL S. PhILIPPOFF ${ }^{* * *}$

\title{
REEXAMINING THE ECONOMIC RECOVERY TAX ACT OF 1981: EVIDENCE FROM INNOVATIVE EFFICIENCY
}

Keywords: R\&D, tax credit, innovation, policy evaluation.

J E L Classification: G18, H25, 031, 034.

Abstract: The research objective of this article is to examine the Economic Recovery Tax Act of 1981 (ERTA) on innovative efficiency, which measures how effectively firms convert research spending and existing human capital into new patents and products. Research method- wise, this study measures innovative efficiency by dividing the number of new patents to average R\&D expenses and analyses how innovative efficiency changed after the ERTA using regression. The main conclusion is that the ERTA tax credit decreased innovative efficiency and competitions for research resources could

Date of submission: March 21, 2021; date of acceptance: May 12, 2021.

* Contact information: zhaochu@umich.edu, UM-Flint School of Management 2145 Riverfront Center Flint, Michigan 48502, phone: +(810) 762-0019; ORCID ID: https://orcid.org/0000-0002-8022-9459.

** Contact information: iryna.p.lytvynenko@gmail.com, 11301 Grand Oak Dr, Grand Blanc, Michigan 48439, phone: +(810) 579-6535; ORCID ID: https://orcid.org/00000001-8727-6066.

*** Contact information: karl.philippoff@gmail.com, 46 Macleay Road Montville, NJ 07045, phone: +(973) 270-4195; ORCID ID: https://orcid.org/0000-0002-7649-5068. 
explain this reduction. These findings provide new insights on the effectiveness of R\&D tax policies from the efficiency perspective. Policy makers should consider these findings when designing $R \& D$ tax policies in the future.

\section{IIIIRTODUCTION}

Innovation refers to a new idea or method or the process used to introduce the idea or method, and is crucial to a country's economic development. Since private research is not always sufficient for innovation, many countries use tax credits to encourage private research spending. The U.S. government introduced its first tax incentive for research and development (R\&D) in the Economic Recovery Tax Act of 1981 (ERTA), and has since modified it many times. Policymakers and researchers often debate the effectiveness of the R\&D tax credit and discuss how to improve it. This paper provides new insights on this debate based on innovative efficiency.

First, proponents frequently criticize two shortcomings of the U.S. R\&D tax credit. The first one is the temporary nature of the credit which has expired eight times and been renewed 14 times since 1981. This temporary nature makes it difficult for companies to design budgets for future projects. Second, the U.S. R\&D tax credit is not as competitive as those of other nations. Stewart, Warda and Atkinson (2012) find that the U.S. was ranked only 27th based on $R \& D$ tax incentives among 42 countries. In addition to higher credit rates for R\&D, some nations, such as the United Kingdom and France, provide additional deduction for revenue earned from innovation (Mohnen, Vankan \& Verspagen, 1997; Gaessler, Hall \& Harhoff, 2021).

Second, opponents question the efficacy of R\&D tax credits. First of all, private companies conduct research regardless of any tax credit available. Second, over $80 \%$ of the credit claimed is allocated to multinational companies such as Apple and Microsoft, which likely do not need additional incentives to conduct research. Third, rankings of R\&D tax credits compare only the generosity of governmental policies, but do not reflect actual spending of firms. Although ranked 27th in terms of tax incentives, the U.S. was ranked $1^{\text {st }}$ in total R\&D spending and $10^{\text {th }}$ in R\&D spending as a percentage of total GDP in 2012 (Stewart et al., 2012). These findings suggest that a more generous $R \& D$ tax credit is not necessary to spur private research expenditures. 
Prior literature has extensively studied how tax incentives affect R\&D expenditures and the tradeoff between tax revenue foregone and additional private research investment generated (Hall, 1993; Szlęzak-Matusewicz, 2014; Kahn, 2018; Ziółkowska, 2018). In terms of tax revenue loss, Ernst and Young (2008) find that total R\&D tax credits claimed are $\$ 4.4$ billion, $\$ 6.4$ billion, and $\$ 6.4$ billion in 1997, 2001, and 2005 respectively. However, researchers show that the tax incentive has spurred more private R\&D spending than tax revenue foregone (Berger, 1993; Hall \& Van Reenen, 2000; Edler \& Fagerberg, 2017).

The innovation process involves inputs such as R\&D expenditures and human capital, and outputs such as new patents and products. R\&D expenditure captures only the input perspective of the innovation process. Efficiency, which measures how effectively a firm utilizes its research inputs, is another factor that affects innovation outputs. Innovative efficiency increases when same research inputs generate more outputs or fewer research inputs generate same outputs. An increase in R\&D spending likely leads to more innovation outputs but not necessarily a higher ratio of innovation outputs to inputs. An increase in innovative efficiency could lead to more innovations for firms and the economy in the long run. Researchers have not studied how U.S. R\&D tax credits impact innovative efficiency, and this paper seeks to bridge the gap.

The R\&D tax credit can either increase or decrease innovative efficiency. On the one hand, the credit could increase the efficiency through improving factors that are important for innovation. Some of these factors include research spending, human capital, and organizational structures such as corporate culture and reward system. An increase in available cash through the tax credit allows firms to purchase better equipment and hire more experienced scientists and engineers. The R\&D tax credit also sends a signal to managers about the importance of innovation, and managers could make firms more innovationfriendly. Organizational structures that favor innovation help firms to attract and retain more qualified employees who are essential to successful research. On the other hand, innovative efficiency can also decrease as a result of the R\&D tax credit. The credit reduces the cost for research and increases competition and aggregate demand for R\&D resources. Since research supplies are relatively inelastic (Hall \& Lerner, 2010), additional R\&D inputs can drive up prices of these resources instead of quantities in the short term (Berger, 1993). This increase in prices reduces innovation outputs for every additional dollar spent on $R \& D$, thus reducing innovative efficiency. In addition, although there is an in- 
crease in available cash from the tax credit, their overall innovative efficiency could also drop if firms continue to invest in less promising research projects.

We first test whether the R\&D tax credit increases innovative efficiency for all the firms. We use the NBER patent database and measure innovation as the number of new patents. We then follow Hall, Jaffe and Trajtenberg (2005) and define innovative efficiency by dividing the number of patents to average R\&D expense. The empirical results show that the Economic Recovery Tax Act of 1981 on average leads to lower innovative efficiency.

We next explore mechanisms that could cause the drop in innovative efficiency. One possible mechanism is increased competitions for $R \& D$ resources. Since R\&D resources are relatively inelastic in the short run, higher demand means prices of research resources will increase, reducing innovative efficiency. Firms in more competitive industries likely have higher demand for R\&D resources than those in less competitive industries. If competitions for research resources cause any change in innovative efficiency, the effect will be more significant for companies in competitive industries than those in less competitive ones. We measure industry competition using the Herfindahl index and find that there is a greater drop in innovative efficiency for companies in more competitive industries. This result provides evidence that the R\&D tax incentive increased demand for research resources, leading to lower innovative efficiency.

This study makes the following contributes to the literature. First, policymakers and stakeholders frequently discuss whether the U.S. R\&D tax credit should be permanently extended, and this paper provides a new perspective to this discussion. The traditional input-based R\&D tax credit increases innovative efficiency for more financially constrained firms, but reduces the efficiency for less financially constrained firms. Second, recent literature in economic and finance journals use patenting activities to examine how various non-tax factors impact innovation. This study complements this literature from the tax perspective. Third, prior literature focuses on either inputs or outputs of the innovation process, and has not studied how tax incentives impact innovative efficiency, which measures how effectively firms convert inputs into outputs.

\section{Research Methodology ANd Research Process}

The U.S. Congress introduced its first tax credit for R\&D expenses in 1981 in order to encourage private R\&D spending. Federal tax law provides two mech- 
anisms for firms to recoup the initial costs of their investment in R\&D: a full deduction for qualified research expenditures (QRE) under section 174 and a nonrefundable tax credit that is equal to a percentage of the difference between QRE and a base amount under Internal Revenue Code section 41. A firm's baseline is defined to be $50 \%$ of its current spending or its average QRE over the previous three years, whichever is greater, and the credit is initially set to be $25 \%$ of R\&D spending above the baseline.

Since the inception of the U.S. R\&D tax credit in 1981, researchers have extensively studied its impact on R\&D spending and the results are mixed. Hall (1993) finds that, for every dollar of tax revenue foregone, the tax incentive stimulated $\$ 2.00$ of R\&D spending. Similarly, Berger (1993) calculates the effect to be $\$ 1.25$ induced R\&D expense per dollar of revenue foregone. In contrast, Tillinger (1991) and McCutchen (1993) find that the effect is only $\$ 0.19$ and between $\$ 0.29$ and $\$ 0.35$ respectively for every dollar of tax revenue foregone.

Prior studies have also examined the impact of $R \& D$ tax policies on the research output such as patents and citations per patents. Cappelen, Raknerud and Rybalka (2011) use a governmental tax-based incentive from Norway and investigate how this policy impacts innovation. They find that firms receiving tax credits develop more production processes and products. Cazrnitzki, Hanel and Rosa (2010) study the impact of R\&D tax credits on the innovation activities of manufacturing companies in Canada. They find that firms that received tax credits develop more original products, and conclude that R\&D tax credits are positively associated with innovation outputs.

Nevertheless, no studies have examined R\&D tax credits impact innovative efficiency. Hall et al. (2005) measure innovative efficiency by dividing the number of patents to research spending. They show the trend of innovative efficiency in the 80s and 90s but do not test what affect the efficiency directly. Aghion, Van Reenen and Zingales (2013) find institutional ownership is associated positively with research outputs and efficiency but the effect on efficiency is larger. Chircop, Collins, Hass and Nguyen (2020) show that innovative efficiency increases when a firm's accounting system is more comparable to its industry peers. Both Merz (2021) and Almeida, Hsu, Li and Tseng (2021) find that innovative efficiency is negatively associated with financial constraint.

In addition, researchers have identified factors that affect the input and output of innovation. Input wise, prior research finds that greater institutional ownership reduces a firm's tendency to reduce R\&D spending following less fa- 
vorable financial performance (Francis \& Smith, 1995; Eng \& Shackell, 2001). Output wise, . Analyst coverage and accounting conservatisam are found to negatively affect intonation due to managerial myopia (He \& Tian, 2013; Chang, Hilary, Kang \& Zhang, 2015). Aghion et al. (2013) find that higher institutional ownership ensures CEOs a secure job and hence helps overcome CEOs' myopia and promotes innovative efficiency. In contrast, greater institutional ownership alleviates managerial myopia and accounting conservatism and increases innovative efficiency (Aghion et al., 2013).

\section{HYPOTHESIS DEVELOPMENT}

R\&D tax credits could either increase or decrease innovative efficiency. Innovation is a complex process and its efficiency depends on many factors. Some of these factors include research spending, qualified employees, and organizational structures such as corporate culture and reward systems. R\&D tax credits could increase innovative efficiency by improving these factors. First, with the additional cash saved from the R\&D incentive, firms are more likely to purchase equipment, upgrade research facilities, and hire better scientists and engineers. Furthermore, the $R \& D$ tax credit could reinforce the importance of innovation and lead to managers to improve their organizational structure. Organizational structures affect innovative efficiency in many ways. For instance, an innovation-friendly corporate culture helps a firm to attract and retain highly talented employees. A reward system that puts less focus on the results of individual research projects reduces employees' career concerns and leads to greater research efforts (Manso, 2011). In addition, flexible working hours accommodate employees' schedules and allow them to determine their own, possibly more efficient, work schedule. If a R\&D favorable policy spurs managers to make firms more innovation-friendly, these firms will likely hire and retain more talented employees, leading to greater efficiency in the use of $\mathrm{R} \& \mathrm{D}$ resources.

On the other hand, the R\&D tax credit could also lower innovative efficiency. $R \& D$ tax credits aim to increase overall private research spending by reducing the cost of innovation, but could also lead to greater competitions for research resources among firms. Research resources, such as human capital, are generally inelastic in the short-run (Hall \& Lerner, 2010), and increases in overall $R \& D$ spending could increase the prices of research resources instead of their 
quantities (Berger, 1993). Thus, increases in R\&D expenditures could be the result of increased price of research inputs instead of quantities of inputs, leading to lower innovative efficiency. Since the R\&D tax credit could either increase or decrease innovative efficiency, the actual effect is ultimately an empirical question, we make no prediction about how the ERTA R\&D credit impact innovative efficiency.

$\mathrm{H}_{1}$ : The $1981 \mathrm{R} \& \mathrm{D}$ tax credit does not change innovative efficiency.

We then investigate possible mechanisms that drive the change in innovative efficiency following the institution of the 1981 U.S. tax credit. One possibility is competitions for research resources. Demand for $\mathrm{R} \& \mathrm{D}$ resources will likely increase in more competitive industries, leading to higher price increases. If competitions for research resources reduce in innovative efficiency, the effect will be more significant for firms in competitive industries than for those in less competitive ones.

$\mathrm{H}_{2}$ : The effect of the $1981 \mathrm{R} \& \mathrm{D}$ tax credit on innovative efficiency is more significant for firms in competitive industries than for those in less competitive industries.

\section{DATA AND VARIABLES}

This study combines accounting data from Compustat and innovation data from the National Bureau of Economic Research (NBER) patent database initiated by Hall, Jaffe and Trajtenberg (2001). The database includes patent number, associated companies, accumulated number of citations, locations from which patents are filed, application year, grant year, the number of citations, and the 6-digit cusip number for each company in the database that allows researchers to combine the Compustat database with the patent database. We exclude firms in the financial services and utility industries, and firms whose R\&D expense is less than $2 \%$ of net sales. The final sample has 16,251 firm-year observations from 1975 to 2017. 
Appendix A. Variable Definitions

\begin{tabular}{|c|c|}
\hline \multicolumn{2}{|c|}{ Dependent variables } \\
\hline \multirow[t]{2}{*}{$P A T \_R D_{t-n-1, t-1}$} & $\begin{array}{l}P A T_{-} R D_{t-2, t-1,} P A T_{-} R D_{t-3, t-1,} \text { and } P A T_{-} R D_{t-4, t-1} \text { denote the natural logarithm of one plus a firm's } \\
\text { total number of patents in year } t \text { over average } R \& D \text { expense in the prior two, three, and } \\
\text { four years, respectively. The number of patents is corrected for truncation bias for each } \\
\text { year. }\end{array}$ \\
\hline & $=P A T_{-} R D_{t-n-1, t-1}=\operatorname{Ln}\left(\frac{1+P A T_{t}}{\left(\sum_{t-n-1}^{t-1} R D_{m}\right) / n}\right), n=1,2$, or 3 \\
\hline \multicolumn{2}{|c|}{ Variables of Interest } \\
\hline $\begin{array}{l}D 1981_{t} \\
H_{-} I N D E X_{t}\end{array}$ & $\begin{array}{l}\text { A dummy variable equals to } 1 \text { if a firm-year observation is after } 1981 \text {, and } 0 \text { other wise. } \\
\text { Herfindahl index of a firm in year } t \text { constructed based on sales for } 2 \text {-digit SIC industry } \\
\text { classification. }\end{array}$ \\
\hline$H_{-} I N D E X_{t}^{2}$ & The square term of $H_{-} I N D E X_{t}$ \\
\hline D1981 $\times$ XINDEX $X_{t}$ & An interaction variable as the product of $D 1981_{t}$ and $H_{-} I N D E X_{t}$ \\
\hline \multicolumn{2}{|l|}{ Control Variables } \\
\hline \multirow[t]{2}{*}{$\begin{array}{l}A G E_{t} \\
Q_{t}\end{array}$} & $\begin{array}{l}\text { The number of years that the firm is listed on Compustat with a non-missing stock price. } \\
\text { Assets +year-end stock price*year-end shares -book equity }\end{array}$ \\
\hline & Vlarket to book ratio. $\stackrel{\text { Assets }}{\longrightarrow}$ \\
\hline$R D_{t}$ & R\&D expense deflated by net sales. \\
\hline $\operatorname{LEVERAGE}_{t}$ & The ratio of total debt to total assets. $\frac{\text { Total debt }}{\text { Assets }}$ \\
\hline TANGIBILITY $_{t}$ & The ratio of net PPE to total assets. $\frac{N P P E}{\text { Assets }}$ \\
\hline PROFITABILITY & The ratio of EBIDTA to total assets. $\frac{\text { EBITDA }}{\text { Assets }}$ \\
\hline$S I Z E_{t}$ & Natural logarithm of inflation-adjusted book assets. \\
\hline$S I Z E_{t}^{2}$ & The square of $S I Z E_{t}$ \\
\hline
\end{tabular}

S o u r c e : appendix table created by the authors.

There are a few issues measuring innovative efficiency. First, the R\&D process takes time; it may be years from the start of a project to the moment that a patent is ready for application. The total spending that leads to one particular patent includes $\mathrm{R} \& \mathrm{D}$ spending in prior years and is hard to directly calculate. Second, firms usually engage in multiple research projects at the same time, but only present total research expenditures in a given year in their financial statements. Since only a portion of total R\&D expenses in a year contribute to a particular patent, it is difficult to match exact research expenses to specific patents. To overcome these issues, we consider mean R\&D expenditures in the two, three, or four years before patent application. Since approximately half of research spending is the wages of employees, and firms smooth this spending over time, we assume that $R \& D$ expenses that contribute one particular patent are similar each year on average. For all patents filed in a given year, average annual research spending from prior years provides a proximate value of total annual expenditure for these patents. 
$P A T_{-} R D_{t-n-1, t-1}=\operatorname{Ln}\left(\frac{1+P A T_{t}}{\left(\sum_{t-n-1}^{t-1} R D_{m}\right) / n}\right), n=1,2$, or 3

$P A T_{-} R D_{t-n-1, t-1}=$ a firm's innovative efficiency in year $t$

$P A T_{t}=$ a firm's total number of patents applied in year $t$ and eventually granted $R D_{m}=\mathrm{R} \& \mathrm{D}$ spending in year $m$

Equation (1) shows the first measure of innovative efficiency. It is defined by dividing successful patent applications to average R\&D spending over two, three, and four years prior to patent application. This variable design provides the best possible match of the aggregate research spending to new patents filed in a given year. We construct variables using application year instead of grant year to better reflect the year of innovation (Griliches, Pakes \& Hall, 1987).

However, there are some drawbacks in using patenting activity to study innovation. First, the NBER patent database suffers from truncation bias since un-granted patents are excluded. On average, the gap between a patent's application and grant years is two years. It is thus not surprising that there are more patents in earlier years in the database. To address this issue, we divide a firm's total patents in a given year by the average number of patents in the same year and technology class (Hall et al., 2001). Second, some firms do not file patents because some innovations are not patentable or because firms want to keep their innovations secrets. Nevertheless, we believe that empirical design with an adequate control for heterogeneity will mitigate these concerns and provide a sound inference.

Following prior literature (Fang, Tian \& Tice, 2014; Atanassov, 2013), we control for the following variables: firm size $\left(S I Z E_{t}\right)$, firm age $\left(A G E_{t}\right)$, growth opportunities $\left(Q_{t}\right)$, leverage ( $\left.L E V E R A G E_{t}\right)$, tangibility (TANGIBILITY), and profitability (PROFITABILITY). Appendix A includes detailed definitions of all variables. 


\section{EMPIRICAL DESIGNS}

To test H1, we run the regression using Equation (2). We first define the dummy variable, $D 1981^{\prime}$, to be zero if a firm-year is before 1982 , and one otherwise. Coefficients of $D 1981_{t}$ indicate how the 1981 tax credit affects on innovative efficiency. The regression model includes various control variables and controls for year and industry fixed effects.

INNOVATIVE EFFICIENCY $Y_{t}=\beta_{0}+\beta_{1} \times D 1981_{t}+\sum \beta \times$ Control Variables $_{t}+\varepsilon_{t}$

To test $\mathrm{H} 2$, we run the regression using Equation (3). We measure industry competition using the Herfindahl index, HINDEX $_{t}$. The formula for the HINDEX is in Equation (2). Higher HINDEX indicates higher industry competition. We use 4-digit SIC codes for industry classification and compute this index using all available data from Compustat. We also calculate $H I N D E X^{2}{ }_{t}$, the square of $H_{I N D E X_{t}}$, to control for any non-linear nature of this index. Coefficients of $H I N$ $D E X_{t}$ indicate the effect of industry competition on any change in innovative efficiency, regardless of any R\&D tax credit. D1981 $\times H_{t} I N D E X_{t}$ is an interaction variable as the product of $D 1981_{t}$ and $H I N D E X_{t^{\prime}}$ and is the variable of interest. Coefficients of $D 1981_{t} \times H I N D E X_{t}$ indicate any incremental impact of industry competition on innovative efficiency after the tax credit becomes available.

$$
\begin{aligned}
& \text { INNOVATIVE EFFICIENCY }=\beta_{0}+\beta_{1} \times \text { DI }_{t} 981_{t}+\beta_{2} \times D 1981_{t} \times \text { HINDEX }_{t}+ \\
& \beta_{3} \times \text { HINDEX }_{t}+\beta_{4} \times \text { HINDEX }_{t}+\sum \beta \times \text { Control Variables }_{t}+\varepsilon_{t} \\
& \text { HINDEX }_{i t}=\sum_{i=1}^{n}\left(\frac{\text { sale }_{i t}}{\sum_{i=1}^{n} \text { Sale }_{i t}}\right)^{2}
\end{aligned}
$$

\section{Results of the Research Process}

Summary statistics are presented in table 1 . Panel A reports the summary statistics of the dependent variables. On average, $\$ 1$ million annual increase in R\&D spending in the last two, three, and four years leads to $2.133,3.269$, and 
4.635 new patents. Panel B reports the descriptive statistics for variables of interest. The mean of $D 1981_{t}$ is 0.902 and suggests that about $90 \%$ of firm-year observations occur after the inception of the tax credit. The average market competition level is $14.8 \%$. Panel C reports the summary statistics of the control variables. On average, firms have a leverage ratio of 0.188 , a net PPE to total asset ratio of 0.335 , a profit margin of 0.154 , a Tobin's $Q$ of 1.152 , and have been publicly traded for 31 years.

Table 1. Summary Statistics

\begin{tabular}{|c|c|c|c|c|c|c|}
\hline Variable & Mean & SD & p25 & p50 & p75 & $\mathbf{N}$ \\
\hline \multicolumn{7}{|c|}{ Panel A: Dependent Variables: Innovative efficiency } \\
\hline$P A T_{-} R D_{t-2, t-1}$ & -0.217 & 1.270 & -1.014 & -0.219 & 0.608 & 16,251 \\
\hline$P A T_{-} R D_{t-3, t-1}$ & 0.245 & 1.265 & -0.543 & 0.241 & 1.166 & 16,251 \\
\hline$P A T_{-} R D_{t-4, t-1}$ & 0.559 & 1.278 & -0.272 & 0.550 & 1.502 & 16,251 \\
\hline \multicolumn{7}{|c|}{ Panel B: Variables of Interest } \\
\hline$D 1981_{t}$ & 0.902 & 0.301 & 1 & 1 & 1 & 16,251 \\
\hline$H_{I N D E X_{t}}$ & 0.148 & 0.170 & 0.066 & 0.133 & 0.247 & 16,251 \\
\hline HINDEX $_{t}{ }_{t}$ & 0.022 & 0.026 & 0.004 & 0.018 & 0.061 & 16,251 \\
\hline$D 1981_{t} \times$ HINDEX $_{t}$ & 0.133 & 0.052 & 0.065 & 0.134 & 0.250 & 16,251 \\
\hline \multicolumn{7}{|c|}{ Panel C: Control Variables } \\
\hline$L_{E V E R A G E}$ & 0.188 & 0.215 & 0.072 & 0.193 & 0.309 & 16,251 \\
\hline TANGIBILITY ${ }_{t}$ & 0.335 & 0.118 & 0.226 & 0.342 & 0.421 & 16,251 \\
\hline PROFITABILITY ${ }_{t}$ & 0.154 & 0.120 & 0.113 & 0.177 & 0.238 & 16,251 \\
\hline$Q_{t}$ & 1.152 & 1.721 & 0.613 & 1.088 & 1.839 & 16,251 \\
\hline SIZE $_{t}$ & 6.209 & 2.453 & 4.337 & 6.417 & 7.602 & 16,251 \\
\hline$S I Z E^{2}{ }_{t}$ & 38.792 & 28.159 & 18.810 & 41.178 & 57.790 & 16,251 \\
\hline$A G E_{t}$ & 31.184 & 12.410 & 13 & 32 & 46 & 16,251 \\
\hline \multicolumn{7}{|c|}{$\begin{array}{l}\text { This table reports the descriptive statistics of the sample, including mean, standard deviation, } 25 \text { th percentile, median, } \\
\text { 75th percentile, and the number of observations. Panel A presents the summary statistics of dependent variables. } \\
\text { Panel B presents the summary statistics of variables of interest. Panel C presents the summary statistics of control vari- } \\
\text { ables. All variables are constructed from } 1975 \text { to } 2017 \text {. Variables are defined in the Appendix A. }\end{array}$} \\
\hline
\end{tabular}

S o u r c e : summary statistics table created by the authors using SAS and Stata. 
Table 2 provides the empirical results for the first hypothesis. Coefficients of $D 1981_{t}$ are negative and significant, suggesting that the 1981 tax credit, on average, decreased the innovative efficiency. In terms of economic significance, firms created an average 0.35 fewer patents for $\$ 1$ million annual increase in research investment after 1981. For control variables, TANGIBILITY $Y_{t}$ and PROFITABILITY $Y_{t}$ both have positive coefficients, suggesting that firms with more facilities and net income generally have higher innovative efficiency. In addition, firms with greater growth potential, $Q_{t}$, small firms, and younger firms all have higher innovative efficiency.

Table 2. The $1981 \mathrm{R} \& \mathrm{D}$ Tax Credit and Innovative efficiency $\left(\mathrm{H}_{1}\right)$

\begin{tabular}{|c|c|c|c|}
\hline Variables & $\operatorname{Ln}\left(\frac{1+P A T_{t}}{\left(\sum_{t-2}^{t-1} R D_{m}\right) / 2}\right)$ & $\begin{array}{c}\text { (2) } \\
\operatorname{Ln}\left(\frac{1+P A T_{t}}{\left(\Sigma_{t-3}^{t-1} R D_{m}\right) / 3}\right)\end{array}$ & $\begin{array}{c}\text { (3) } \\
\operatorname{Ln}\left(\frac{1+P A T_{t}}{\left(\sum_{t-4}^{t-1} R D_{m}\right) / 4}\right)\end{array}$ \\
\hline \multirow[t]{2}{*}{ D1981 } & $-0.55^{* * *}$ & $-0.54 * * *$ & $-0.52^{* * *}$ \\
\hline & $(0.12)$ & $(0.13)$ & $(0.11)$ \\
\hline \multirow[t]{2}{*}{ Leverage } & -0.23 & -0.09 & -0.17 \\
\hline & $(0.22)$ & $(0.26)$ & (0.19) \\
\hline \multirow[t]{2}{*}{ Tangebility } & $1.13^{* * *}$ & $1.09 * * *$ & $1.12^{* * *}$ \\
\hline & $(0.11)$ & $(0.23)$ & $(0.28)$ \\
\hline \multirow[t]{2}{*}{ Profitability } & $1.29 * * *$ & $1.32^{* * *}$ & $1.37^{* * *}$ \\
\hline & $(0.18)$ & $(0.21)$ & $(0.16)$ \\
\hline \multirow[t]{2}{*}{$a_{t}$} & $0.05^{* * *}$ & $0.06^{* * *}$ & $0.05^{* * *}$ \\
\hline & $(0.01)$ & $(0.01)$ & $(0.01)$ \\
\hline \multirow[t]{2}{*}{ Size } & $-0.35 * * *$ & $-0.33^{* * *}$ & $-0.36^{* * *}$ \\
\hline & $(0.12)$ & $(0.09)$ & $(0.11)$ \\
\hline \multirow[t]{2}{*}{ Size_square } & $0.05^{* * *}$ & $0.05^{* * *}$ & $0.06^{* * *}$ \\
\hline & $(0.01)$ & $(0.01)$ & $(0.02)$ \\
\hline \multirow[t]{2}{*}{ Age } & $-0.03^{* * *}$ & $-0.02^{* * *}$ & $-0.03^{* * *}$ \\
\hline & $(0.00)$ & $(0.00)$ & $(0.01)$ \\
\hline Constant & $2.56^{* * *}$ & $3.24^{* * *}$ & $3.51^{* * *}$ \\
\hline
\end{tabular}




\begin{tabular}{|l|c|c|c|}
\hline \hline \multicolumn{1}{|c|}{ Variables } & (1) & (2) & (3) \\
& $\operatorname{Ln}\left(\frac{1+P A T_{t}}{\left(\sum_{t-2}^{t-1} R D_{m}\right) / 2}\right)$ & $\operatorname{Ln}\left(\frac{1+P A T_{t}}{\left(\sum_{t-3}^{t-1} R D_{m}\right) / 3}\right)$ & $\operatorname{Ln}\left(\frac{1+P A T_{t}}{\left(\sum_{t-4}^{t-1} R D_{m}\right) / 4}\right)$ \\
\hline \hline & $(0.53)$ & $(0.78)$ & (0.62) \\
\hline Observations & 16,251 & 16,251 & 0.35 \\
\hline Adj. R-squared & 0.34 & 0.34 & 16,251 \\
\hline $\begin{array}{l}\text { This table presents the empirical results for the first hypothesis. All variables are defined in Appendix A. All mo- } \\
\text { dels include industry fixed effects but the coefficients are not reported. Robust standard errors are in parenthe- } \\
\text { sis. }{ }^{*}, * *, * * * \text { denote significance at } 10 \%, 5 \%, \text { and } 1 \% \text { levels with two tails. }\end{array}$ \\
\hline
\end{tabular}

S o u r c e : regression results created by the authors using SAS and Stata.

Table 3 shows the empirical results for the second hypothesis. Coefficients of D1981t are still negative and significant, confirming the finding in the first hypothesis. Coefficients of HINDEXt are not significant, indicating that competitions for resources generally do not impact innovative efficiency before the 1981 tax credit. However, negative and significant coefficients of D1981t $\times$ HINDEXt suggest that competitions for resources reduce innovative efficiency after the 1981 tax credit. For a one standard deviation increase in industry competition level, firms on average have 0.18 fewer patents for $\$ 1$ million annual increase in $R \& D$ investment after the 1981 tax credit. Empirical findings and inferences for the control variables are consistent with those found in table 2 .

Table 3. Innovative efficiency and Industry Competition $\left(\mathrm{H}_{2}\right)$

\begin{tabular}{|c|c|c|c|}
\hline Variables & $\begin{array}{c}\text { (1) } \\
\operatorname{Ln}\left(\frac{1+P A T_{t}}{\left(\sum_{t-2}^{t-1} R D_{m}\right) / 2}\right)\end{array}$ & $\begin{array}{c}\text { (2) } \\
\operatorname{Ln}\left(\frac{1+P A T_{t}}{\left(\sum_{t-3}^{t-1} R D_{m}\right) / 3}\right)\end{array}$ & $\operatorname{Ln}\left(\frac{1+P A T_{t}}{\left(\sum_{t-4}^{t-1} R D_{m}\right) / 4}\right)$ \\
\hline \multirow[t]{2}{*}{ D1981 } & $-0.66^{* * *}$ & $-0.64 * * *$ & $-0.63^{* * *}$ \\
\hline & $(0.17)$ & $(0.21)$ & (0.19) \\
\hline \multirow[t]{2}{*}{ D1981×Hindex } & $-0.92^{* * *}$ & $-0.97^{* * *}$ & $-1.02^{* * *}$ \\
\hline & $(0.31)$ & $(0.37)$ & $(0.29)$ \\
\hline Hindex & -0.46 & -0.39 & -0.42 \\
\hline
\end{tabular}


Table 3. Innovative...

\begin{tabular}{|c|c|c|c|}
\hline Variables & $\operatorname{Ln}\left(\frac{1+P A T_{t}}{\left(\sum_{t-2}^{t-1} R D_{m}\right) / 2}\right)$ & $\begin{array}{c}\operatorname{Ln}\left(\frac{1+P A T_{t}}{\left(\sum_{t-3}^{t-1} R D_{m}\right) / 3}\right)\end{array}$ & $\operatorname{Ln}\left(\frac{1+P A T_{t}}{\left(\sum_{t-4}^{t-1} R D_{m}\right) / 4}\right)$ \\
\hline & $(0.81)$ & $(0.63)$ & $(0.72)$ \\
\hline \multirow[t]{2}{*}{ Hindex ${ }^{2}$} & 0.65 & 0.48 & 0.55 \\
\hline & $(0.73)$ & $(0.60)$ & $(0.84)$ \\
\hline \multirow[t]{2}{*}{ Leverage } & -0.27 & -0.17 & -0.21 \\
\hline & $(0.31)$ & $(0.29)$ & $(0.25)$ \\
\hline \multirow[t]{2}{*}{ Tangebility } & $1.16^{* * *}$ & $1.12^{* * *}$ & $1.17 * * *$ \\
\hline & $(0.23)$ & $(0.31)$ & (0.29) \\
\hline \multirow[t]{2}{*}{ Profitability } & $1.33 * * *$ & $1.36 * * *$ & $1.35^{* * *}$ \\
\hline & $(0.25)$ & $(0.33)$ & $(0.37)$ \\
\hline \multirow[t]{2}{*}{ Tobin_q } & $0.05^{* * *}$ & $0.05^{* * *}$ & $0.06 * * *$ \\
\hline & $(0.01)$ & $(0.01)$ & $(0.01)$ \\
\hline \multirow[t]{2}{*}{ Size } & $-0.32 * * *$ & $-0.35 * * *$ & $-0.33 * * *$ \\
\hline & (0.09) & $(0.11)$ & $(0.07)$ \\
\hline \multirow[t]{2}{*}{ Size_square } & $0.05^{* * *}$ & $0.05^{* * *}$ & $0.05^{* * *}$ \\
\hline & $(0.01)$ & $(0.02)$ & $(0.02)$ \\
\hline \multirow[t]{2}{*}{ Age } & $-0.04 * * *$ & $-0.03 * * *$ & $-0.03 * * *$ \\
\hline & $(0.01)$ & $(0.01)$ & $(0.01)$ \\
\hline \multirow[t]{2}{*}{ Constant } & $2.81 * * *$ & $2.59 * * *$ & $3.27^{* * *}$ \\
\hline & $(0.63)$ & $(0.50)$ & $(0.88)$ \\
\hline Observations & 16,251 & 16,251 & 16,251 \\
\hline Adj. R-squared & 0.35 & 0.35 & 0.36 \\
\hline \multicolumn{4}{|c|}{$\begin{array}{l}\text { This table presents the empirical results for the second hypothesis. All variables are defined in Appendix A. All } \\
\text { models include industry fixed effects but the coefficients are not reported. Robust standard errors are in paren- } \\
\text { thesis. } *, * *, * * \text { denote significance at } 10 \%, 5 \% \text {, and } 1 \% \text { levels with two tails. }\end{array}$} \\
\hline
\end{tabular}

S o u r c e : regression results created by the authors using SAS and Stata. 


\section{CONCLUSION}

This paper investigates how the Economic Recovery Tax Act of 1981 impacts innovative efficiency. We show that the R\&D tax policy reduces innovative efficiency and competitions for research resources can explain this reduction. This study provides a new perspective on R\&D tax credits from an efficiency standpoint. Researchers can apply the findings of this paper in an international context. Countries vary in innovation efficiencies due to differences in their infrastructures, copyright laws, and other factors. When examining the attractiveness of R\&D investment across countries, researchers should consider both $R \& D$ tax credits and innovative efficiency in each nation.

\section{REFERENCES}

Aghion, P., Van Reenen, J., \& Zingales, L. (2013). Innovation and institutional ownership. American Economic Review, 103(1), 277-304. http://dx.doi.org/10.1257/ aer.103.1.277.

Almeida, H., Hsu, P., Li, D., \& Tseng, K. (2021). More cash, less innovation: The effect of the American Jobs Creation Act on patent value. Journal of Financial and Quantitative Analysis, 56(1), 1-28. http://dx.doi.org/10.1017/S0022109019000954.

Atanassov, J. (2013). Do hostile takeovers stifle innovation? Evidence from antitakeover legislation and corporate patenting. Journal of Finance, 68(3), 1097-1131. http:// dx.doi.org/10.1111/jofi.12019.

Berger, P. (1993). Explicit and implicit tax effects of the R\&D tax credit. Journal of Accounting Research, 31(2), 131-171. http://dx.doi.org/10.2307/2491268.

Cappelen, A., Raknerud, A., \& Rybalka, M. (2011). The effects of R\&D tax credits on patenting and innovations. Research Policy, 41(2), 334-345. http://dx.doi.org/10.1016/ j.respol.2011.10.001.

Cazrnitzki, D., Hanel, P., \& Rosa, J.M. (2010). Evaluating the impact of R\&D tax credits on innovation: a microeconometric study on Canadian firms. Research Policy, 49(2), 217-229. http://dx.doi.org/10.1016/j.respol.2010.09.017.

Chang, X., Hilary, G., Kang, H., \& Zhang, W. (2015). Innovation, Managerial Myopia, and Financial Reporting. INSEAD Working Paper, 2013/35/AC. http://dx.doi.org/10.2139/ ssrn.2189938.

Chircop, J., Collins, D.W., Hass, L.H., \& Nguyen, N.Q. (2020). Accounting comparability and corporate innovative efficiency. The Accounting Review, 95(4), 127-151. http:// dx.doi.org/10.2308/accr-52609.

Edler, J., \& Fagerberg, J. (2017). Innovation policy: what, why, and how. Oxford Review of Economic Policy, 33(1), 2-23. http://dx.doi.org/10.1093/oxrep/grx001. 
Eng, J.J., \& Shackell, M. (2001). The implications of long-term performance plans and institutional ownership for firms' research and development (R\&D) investments. Journal of Accounting, Auditing, and Finance, 16(2), 117-139. http://dx.doi.org/10.1177/ $0148558 X 0101600204$.

Ernst and Young (2008). Supporting innovation and economic growth: the broad impact of the R\&D tax credit in 2005. London: Ernst and Young.

Fang, V., Tian, X., \& Tice, S. (2014). Does stock liquidity enhance or impede firm innovation? Journal of Finance, 69(5), 2085-2125. http://dx.doi.org/10.1111/jofi.12187.

Francis, J., \& Smith, A. (1995). Agency Costs and Innovation: Some Empirical Evidence. Journal of Accounting and Economics, 19(2-3), 383-409. http://dx.doi. org/10.1016/0165-4101(94)00389-M.

Gaessler, F., Hall, B.H., \& Harhoff, D. (2021). Should there be lower taxes on patent income? Research Policy, 50(1), 104-129. http://dx.doi.org/10.1016/j.respol.2020.104129.

Griliches, Z., Pakes, A., \& Hall, B.H. (1987). The value of patents as indicators of inventive activity. Economic policy and technological performance. In P. Dasgupta, P. Stoneman (Eds.). Economic Policy and Technological Performance. Cambridge: Cambridge University Press. http://dx.doi.org/10.1017/CB09780511559938.006.

Hall, B.H. (1993). R\&D tax policy during the eighties: success or failure? In J. Poterba (Ed.). Tax Policy and the Economy. Cambridge: MIT Press. http://dx.doi.org/10.3386/ w4240.

Hall, B.H., \& Lerner, J. (2010). The financing of R\&D and innovation. In B.H. Hall, N. Rosenberg (Eds.). Handbook of the Economics of Innovation. New York: Elsevier. http://dx.doi.org/10.1016/S0169-7218(10)01014-2.

Hall, B.H., \& Van Reenen, J. (2000). How effective are fiscal incentives for R\&D? A review of the evidence. Research Policy, 29(4-5), 449-470. http://dx.doi.org/10.1016/ S0048-7333(99)00085-2.

Hall, B.H., Jaffe, A., \& Trajtenberg, M. (2001). The NBER patent citation data file: lessons, insights and methodological tools. NBER Working Paper Series, 8498. http://dx.doi. org/10.3386/w8498.

Hall, B.H., Jaffe, A., \& Trajtenberg, M. (2005). Market value and patent citations. The RAND Journal of Economics, 36(1), 16-38.

He, J., \& Tian, X. (2013). The dark side of analyst coverage: the case of innovation. Journal of Financial Economics, 109(3), 856-878. http://dx.doi.org/10.1016/j.jfineco.2013.04.001.

Kahn, K. (2018). Understanding innovation. Business Horizons, 61(3), 453-460. http:// dx.doi.org/10.1016/j.bushor.2018.01.011.

Manso, G. (2011). Motivating innovation. Journal of Finance, 66(5), 1823-1860. http:// doi.org/10.1111/j.1540-6261.2011.01688.x.

McCutchen, W.M. (1993). Estimating the impact of the R\&D tax credit on strategic groups in the pharmaceutical industry. Research Policy, 22(4), 337-351. http:// dx.doi.org/10.1016/0048-7333(93)90004-2. 
Merz, M. (2021). Innovative efficiency as a lever to overcome financial constraints in R\&D contests. Economics of Innovation and New Technology, 30(3), 284-294. http:// dx.doi.org/10.1080/10438599.2019.1695946.

Mohnen, P., Vankan, A., \& Verspagen, B. (2017). Evaluating the innovation box tax policy instrument in the Netherlands, 2007-2013. Oxford Review of Economic Policy, 33(1), 141-156. http://dx.doi.org/10.1093/oxrep/grw038.

Stewart, L.A., Warda, J., \& Atkinson, R. (2012). We're \#27: the United States lags far behind in R\&D tax incentive generosity, https:/itif.org/publications/2012/07/19/ we\%E2\%80\%99re-27-united-states-lags-far-behind-rd-tax-incentive-generosity.

Szlęzak-Matusewicz, J. (2014). Models of Tax Incentives for R\&D Activities of Enterprises in European Union Countries. Copernican Journal of Finance \& Accounting, 3(1), 145-160. http://dx.doi.org/10.12775/CJFA.2014.012.

Tillinger, J.W. (1991). An analysis of the effectiveness of the research and experimentation tax credit in a model of valuation. The Journal of the American Taxation Association, 13(2), 1-29.

Ziółkowska, W. (2018). Innovativeness of the Polish economy in the context of sustainable development. Copernican Journal of Finance \& Accounting, 7(3), 71-88. http:// dx.doi.org/10.12775/ CJFA.2018.016. 